\title{
СОЦІАЛЬНІ ОСНОВИ НАЛЕЖНОӤ ПРАВОВОЇ ПОЛІТИКИ У СФЕРІ ПРАЦІ МЕДИЧНОГО ПЕРСОНАЛУ
}

\author{
ЖАРОВСЬКА Ірина Мирославівна - доктор юридичних наук, професор, \\ професор кафедри теорії та філософії права, конституційного та міжнародного \\ права Національного університету «Јьвівська політехніка»
}

УДК 342.7

DOI 10.32782/EP.2021.2.1

\begin{abstract}
Статтю присвячено дослідженню соціальної основи належної правової політики у сбері праці медичного персоналу. Констатовано, щзо на передовій боротьби із хворобою $\epsilon$ медичний персонал. Трансбормація його трудового та соиіального статусу потребує окремог̈ уваги.

Медичний персонал та пов'язані з ними прачівники зазнають фбізичного та психологічного тиску. Для всіх країн, навіть з розвиненою системою охорони здоров'я, цее суттєва проблема. Проблеми для персоналу включають не тільки збільшене навантаження, спричинене такими спалахами, але також страх перед зараженням для себе та своӥх сімей, роботу з новими та часто змінюваними протоколами та з недосконалими засобами індивідуального захисту, відсутністю засобів догляду за паиієнтами.
\end{abstract}

Зміна сстановища медичних працівників, що спричинені пандемічною кризою стосується збільшення навантаження. Змінні умови прачі передбачають, що нині від медичного працівника вимагається практикувати способи, що відхиляються від звичних стандартів. На індивідуальному рівні доведеться ухвалювати клінічні рішення, які суперечать моралі тих, хто їх приймає. Наприклад, вибір, які пацієнти не отримуватимуть життєзабезпечення, якщо є дебіцит ресурсів. Також вони ризикують життям та здоров'ям. Раптова зміна ролі з медичного працівника на пацієнта з COVID-19 потениійно може призвести до відчуття розчарування, безпорадності та проблем із адаптачією у медичних прачівників, страху.

Пандемії породжують страх, занепокоєння та параною, що може призвести до низки небажаних явищ спільноти, включаючи дискримінацію. Аікарі можуть стати розповсюджувачами хвороби, тому піддаються проявам уникнення, а подекуди $i$ відвертого бізичного переслідування з боку суспільства.

Персонал часто повинен працювати довше і жити поза домом, тим самим порушуючи сімейні стосунки. Суттеве занепокоєння виникає щодо негативних психологічних наслідків під час пандемї, таких як вигорання, втома від співчуттл, тривога, депресія, посттравматичний стресовий розлад, моральна травма.

Ключові слова: пандемія, медичний працівник, дискримінація, трудовий статус, соціальний статус.

\section{Постановка проблеми}

30 січня 2020 р. ВООЗ (Всесвітня організація охорони здоров’я) оголосила про появу нового коронавірусу та 11 березня 2020 року оголосила ії пандемією, що передбачає надзвичайну ситуацію в галузі охорони громадського здоров'я. Пандемія не тільки принесла високий рівень смертності від вірусної інфекції, але й психологічну та психічну катастрофу для решти світу.

Така невизначеність та непередбачуваність спалаху пандемії інфекційного захворювання від її клінічного прояву, причин 


\section{Теорія, історія держави і права, конституційне право}

інфекції, епідеміологічних особливостей, швидкості передачі інфекції, серйозності впливу на громадське здоров'я, новизни, масштабів, наслідків для міжнародного громадського здоров'я та недостатньо підготовлених закладів охорони здоров'я для вирішення спалаху пандемії COVID-19 мають значно високий потенціал для зараження психологічним страхом, і часто призводять до переважної безлічі психологічних проблем, таких як страх, тривога, стигма, упередження, маргіналізація щодо хвороби та їі відношення до всіх людей. Це стосується всіх осіб. Проте на передовій боротьби із хворобою є медичний персонал. Трансформація його трудового та соціального статусу потребує окремої уваги.

\section{Виклад основних положень}

Медичні працівники охорони здоров' я, які піддаються безпосередньому контакту 3 підтвердженими та підозрюваними випадками коронавірусу, вразливі як до інфекцій високого ризику, так і до проблем психічного здоров'я. Медичний персонал та пов'язані з ними працівники зазнають фізичного та психологічного тиску. Для віх країн, навіть з розвиненою системою охорони здоров'я, це суттєва проблема. Проблеми для персоналу включають не тільки збільшене навантаження, спричинене такими спалахами, але також страх перед зараженням для себе та своїх сімей, роботу 3 новими та часто змінюваними протоколами та з недосконалими засобами індивідуального захисту, відсутністю засобів догляду за пацієнтами.

Фахівці констатують, що, «зіткнувшись 3 найбільш руйнівною епідемією інфекційних хвороб за останні 100 років, ми повинні усвідомити, що існує ймовірність набагато серйозніших захворювань та смертей, яких можна уникнути, причому не тільки від хвороби коронавірусу 2019 (COVID-19), але і як наслідків соціальних розладів, спричинених, включаючи страх, відсутністю довіри та структурною дисфункцією в нашій сучасній моделі компенсації за доступ та оплату медичної допомоги» [2].
Розглянемо зміну соціального стану медичних працівників, що спричинені пандемічною кризою.

У першу чергу вказане стосується збільшення навантаження. Там, де догляд зазвичай проходив за принципом 1: 1, при таких спалахах, як COVID-19, медсестри повинні лікувати кількох пацієнтів одночасно [3]. За повідомленням Уряду України у листопаді 2020 року середнє навантаження на одну медичну команду - майже 26 пацієнтів. Для порівняння, у вересні це навантаження становило понад 16 пацієнтів на медичну команду [12].

Змінні умови пращі. Це означає, що від медичного працівника вимагається практикувати способи, що відхиляються від звичних стандартів. На індивідуальному рівні доведеться ухвалювати клінічні рішення, які суперечать моралі тих, хто їх приймає. Наприклад, вибір, які пацієнти не отримуватимуть життєзабезпечення, якщо є дефіцит ресурсів. Іншими словами, саме на персоніфікованому лікареві лежить відповідальність рішення, кому помирати, а кому жити. Ці рішення будуть підтверджені протоколом, але вони відрізняються від звичайної практики та вказівок до COVID-19. Уже зараз співробітники повідомляють, що стурбовані необхідністю ухвалювати ці рішення, називаючи їх «диявольським набором вибору» [6]. Це неймовірна етична проблема, яка перекладена 3 державного рівня на особистісний. Аікарі вказують, що «вже доводилося ухвалювати рішення про розподіл ресурсів щодо того, яких пацієнтів лікувати. Ми не маємо безпосереднього контролю над цими ситуаціями. Більшість країн світу не змогла визнати екзистенційну загрозу цього нового коронавірусу досить рано, щоб повністю підготувати інституційну, місцеву, регіональну, національну та міжнародну мобілізацію та реагування. Політична доцільність, пихатість, науково неадекватні лідери та неповна інформація призвели до цього неадекватного попереднього планування, мінімізуючи загрозу, коли вона 3'явилася» [4].

Ризики для життя та здоров'я. В Етичному кодексі лікарів невідкладної допомо- 
ги СІІА 2017 року вказано, що «сміливість - це здатність виконувати свої обов’язки, незважаючи на особистий ризик чи небезпеку. Аікарі швидкої допомоги виявляють мужність, коли беруть на себе особистий ризик, щоб забезпечити стійку допомогу всім невідкладним пацієнтам, включаючи тих, хто схвильований, агресивний, інфекційний тощо» [1]. Проте це не означає, що лікарі мають обов'язок ризикувати своїм життям заради пацієнта. Раптова зміна ролі 3 медичного працівника на пацієнта 3 COVID-19 потенційно може призвести до відчуття розчарування, безпорадності та проблем із адаптацією в медичних працівників, страху [11]. 3 огляду на те, що заклади охорони здоров'я не готові до цієі неминучої катастрофи, медичні працівники борються з гострою нестачею обладнання - як для лікування пацієнтів, так і для захисту. Загрожуючи особистому життю та здоров'ю сім'ї, вони щодня ухвалюють рішення, чи реалізовувати свій професійний обов'язок, чи ризикувати своїм правом на життя.

Дискриміначія за професійною ознакою. Пандемії породжують страх, занепокоєння та параною, що може призвести до низки небажаних явищ спільноти, включаючи дискримінацію. Аікарі можуть стати розповсюджувачами хвороби, тому піддаються проявам уникнення, а подекуди і відвертого фізичного переслідування 3 боку суспільства. Вказане може кваліфікуватися як професійна дискримінація. «Уже стикаючись 3 емоційними та фізичними негараздами роботи на передовій у битві проти Covid-19, медичні працівники зазнають погроз, насильства та залякування з боку тієї самої громадськості, заради якої вони ризикують своїм життям. Такі агресії зросли по всьому світу протягом останніх місяців під вагою пандемії, стверджують лікарі та неурядові організації, що спостерігають за кризою» [8]. Проблема має загальносвітовий масштаб. Національна рада Мексики щодо запобігання дискримінації повідомили про 265 скарг у зв'язку 3 дискримінацією на основі covid-19 серед працівників охорони здоров'я протягом кількох місяців у 2020 році [9].
ВОО3 вказує, що «характер нападів на охорону здоров'я, пов'язаних 3 COVID-19, сильно варіюеться в різних контекстах i може варіюватися від використання важкої зброї, спрямованої на медичні установи, до стигматизації медичних працівників. Зрештою, незалежно від того, чи вони мають форму кібератаки чи фізичного нападу, вони позбавляють людей терміново необхідної допомоги, загрожують постачальникам медичних послуг та підривають системи охорони здоров'я» [10].

Проблема має настільки розгорнутий характер, що на них змушені реагувати представники влади. Деякі національні та місцеві органи влади запровадили нову політику щодо охорони здоров'я, зокрема в Індії, прийняті зміни до кримінального законодавства, за яким збільшено позбавлення волі за цим злочином до 7 років. У Мексиці деякі міста запровадили спеціальні транспортні послуги для медичних працівників після того, як багатьом відмовили у в’ізді на громадських автобусах.

Трансбормачія трудового та сімейного життя. Останнє виходить на задній план. Персонал часто повинен працювати довше і жити поза домом, тим самим порушуючи сімейні стосунки. Вони ізолюють себе від літніх батьків, дітей та інших членів родини, боячись принести хворобу додому. Змінюеться право на відпочинок, оскільки доволі часто медичний персонал працює понаднормово.

Трудове вигорання та психологічні проблеми. Суттєве занепокоєння виникає щодо негативних психологічних наслідків під час пандемії, таких як вигорання, втома від співчуття, тривога, депресія, посттравматичний стресовий розлад (ПТСР), моральна травма. Стресорами є більша тривалість карантину, страхи перед зараженням, розчарування, нудьга, неадекватні запаси, недостатня інформація, фінансові втрати та стигма.

За даними іноземних науковців, ПТСР у реанімаційних установах на початковому рівні становить 9,6\%. Ризик ПТСР для персоналу передової лінії в цій пандемії може перевищувати 10\% [7]. 


\section{Теорія, історія держави і права, конституційне право}

Перехресне дослідження було проведено в масштабах всієї країни між 16 березня та 26 квітня 2020 року в Польщі. Загалом 2039 респондентів, що представляють усіх постачальників медичних послуг (59,8\%), а також інші спеціалісти. Результати продемонстрували, що медичні працівники частіше виявляли відповідні психопатологічні симптоми (GHQ-28 (Загальний опитувальник-28) загальний бал> 24), ніж немедичні групи (60,8\% проти 48,0\% відповідно), такі як тривога, безсоння та соматичні симптоми навіть після коригування на потенційні незрозумілі фактори [5].

Враховуючи потребу суспільства в їх ефективній та постійній присутності, дуже важливо звертати увагу на їх очікувані потреби . Крім полегшення певних умов для медичних працівників та підвищення економічної складової в системі оплати праці, психологічна підтримка цих людей також дуже важлива. Виявлення їх психічних проблем та вирішення цих потенційних проблем - це перший крок до ефективного правового втручання.

Для медичних працівників та фахівців, які працюють в умовах високого стресу, емоційні та поведінкові реакції є природно адаптивними до екстремального (непередбачуваного та невизначеного) стресу, i тому консультування та психотерапія на основі моделі адаптації до стресу повинні здійснюватися якнайшвидше. Вирішення питань психічного здоров'я медичних працівників має важливе значення для кращої профілактики та контролю за пандемічними проявами. Завданням належної правової політики є раціональне збереження робочої сили та ресурсів у сфері охорони здоров'я.

\section{Висновок}

Реформа медицини в Україні здійснюється довгий період, проте суттєвих зрушень у бік безпечності, доступності та належності надання медичної допомоги та медичних послуг не здійснено. Пандемія COVID-19 загострила проблему соціального та трудового сстатусу медичних працівників. Вони нині опинилися на «передовій» боротьби 3 хворобою, проте ні
3 боку органів публічної влади, ні з боку суспільства загалом підтримки та допомоги не проявляється в достатньому розмірі.

Визначено, що статус медичних працівників змінився під впливом пандемії COVID-19 у наступних аспектах: збільшення навантаження; змінні умови праці; етичні дилеми; ризики для життя та здоров'я; дискримінація за професійною ознакою; трансформація трудового та сімейного життя; трудове вигорання та психологічні проблеми.

\section{Література \\ 1. American College of Emergency} Physicians (ACEP) Code of Ethics for Emergency Physicians. 2017. URL: www.acep. org/globalassets/new-pdfs/policy-statements/ code-of-ethics-for-emergency-physicians.pdf.

2. Barach P., Fisher S. D., Jacob A. M. et al. Disruption of healthcare: Will the COVID pandemic worsen non-COVID outcomes and disease outbreaks? Prog Pediatr Cardiol. 2020. V. 59. doi: 10.1016/j.ppedcard.2020.101254.

3. Einav S, Hick J L, Hanfling D, et al. . Surge capacity logistics: care of the critically ill and injured during pandemics and disasters: CHEST consensus statement. Chest 2014. V. 146. P. $17-143$.

4. Kenneth V. Iserson Healthcare Ethics During a Pandemic West J Emerg Med. 2020 V. 21(3) P. 477-483.

5. Maciaszek J.,Ciulkowicz M., Misiak B., Szczesniak D., Dorota L.,Wieczorek T., Fila-Witecka K., Gawlowski P., Rymaszewska J. Mental Health of Medical and NonMedical Professionals during the Peak of the COVID-19 Pandemic: A Cross-Sectional Nationwide Study J. Clin. Med. 2020, V. 9(8) P. 2527 https://doi.org/10.3390/jcm9082527

6. Senior J Opinion / The Psychological Trauma That Awaits Our Doctors and Nurses. The New York Times. 29 March 2020. URL: https://www.nytimes.com/2020/03/29/ opinion/coronavirus-ventilators-rationingtriage.html? referringSource = articleShare

7. Spencer S A, Nolan J P, Osborn M, et al. The presence of psychological trauma symptoms in resuscitation providers and an exploration of debriefing practices. Resuscitation 2019. V.142. P. 175-181. 
8. Taylor L. Covid-19 misinformation sparks threats and violence against doctors in Latin America BMJ 2020. V. 370 doi: https:// doi.org/10.1136/bmj.m3088

9. Trabajadores de la salud, el tercer grupo que más quejas presenta ante el Conapred [Health workers, the third group with the most complaints presented to Conapred]. La Jornada 2020 May 11. URL: https://www.jornada.com.mx/2020/05/11/ politica/005n2pol. (In Spanish.)

10. WHO. Attacks on health care in the context of COVID-19. 30 July 2020. URL: https://www.who.int/news-room/featurestories/detail/attacks-on-health-care-in-thecontext-of-covid-19

11. Zheng Wei Mental health and a novel coronavirus (2019-nCoV) in China. J. Aff. Disord. 2020 doi: 10.1016/j.jad.2020.03.041.

12. Урядовий портал. Міністерство охорони здоров'я України, За лікування пацієнтів з COVID-19 або з підозрою на нього Національна служба здоров'я виплатила вже понад 8 млрд грн. URL: https://www.kmu.gov.ua/news/za-likuvannyapaciyentiv-z-covid-19-abo-z-pidozroyu-nanogo-nacionalna-sluzhba-zdorovya-viplatilavzhe-ponad-8-mlrd-grn
The article is devoted to the study of the social basis of appropriate legal policy in the field of medical staff. It was stated that medical personnel are at the forefront of the fight against the disease. The transformation of his labor and social status needs special attention.

Medical staff and related staff are under physical and psychological pressure. For all countries, even with a developed health care system, this is a significant problem. Problems for staff include not only the increased workload caused by such outbreaks, but also the fear of infection for themselves and their families, working with new and frequently changing protocols and imperfect personal protective equipment, and lack of patient care.

The change in the situation of medical workers caused by the pandemic crisis concerns the increase in workload. Variable working conditions imply that a healthcare professional is now required to practice methods that deviate from normal standards. At the individual level, we will have to make clinical decisions that are contrary to the morals of those who make them. For example, choosing which patients will not receive a livelihood if there is a shortage of resources. They also risk their lives and health. A sudden change of role from a healthcare professional to a patient with COVID-19 can potentially lead to frustration, helplessness and adaptation problems in healthcare professionals, fear

Pandemics cause fear, anxiety and paranoia, which can lead to a number of community adverse events, including discrimination. Doctors can become spreaders of the disease and are therefore susceptible to avoidance, and sometimes outright physical harassment by society.

Staff often have to work longer and live away from home, thus disrupting family relationships. Significant concerns arise about the negative psychological consequences of a pandemic, such as burnout, compassion fatigue, anxiety, depression, post-traumatic stress disorder, and moral trauma.

Key words: pandemic, health worker, discrimination, labor status, social status. 